\title{
Perbedaan prestasi siswa model pembelajaran kooperatif tipe STAD dan NHT materi koordinat kartesius
}

\author{
Rahman Hidayat ${ }^{1 *}$, Sripatmi², Muhammad Turmuzi², \\ Nani Kurniati ${ }^{2}$
}

\author{
${ }^{1}$ Mahasiswa Pendidikan Matematika, FKIP, Universitas Mataram, Mataram \\ 2 Pendidikan Matematika, FKIP, Universitas Mataram, Mataram
}

rahmanhidayatktr@gmail.com

Diterima: 16-09-2021; Direvisi: 26-09-2021; Dipublikasi: 30-09-2021

\begin{abstract}
This study aims to determine whether there are differences in maths learning achievement between classes taught by cooperative learning model Student Team Achievement Division (STAD) type and class taught by cooperative learning type Numbered Head Together (NHT) in material sistim coordinat cartesius class VIII SMP Negeri 1 Kediri 2018/2019 school year. Data collection techniques in this study are test techniques with instruments in the form of learning achievement test, learning implementation observasion sheets and learning implementation. Data analysis techniques use descriptive statistics. Hypothesis test of students' final ability (posstest) with t-test of two parties at a significance level of $5 \%$ resulted in tcount <ttable namely $0,020<2.030$ which means that there were nothing differences in mathematics learning achievement between classes taught by cooperative learning model Student Team Achievement Division (STAD) and classes taught by the cooperative learning model Numbered Head Together (NHT) in material sistim coordinat cartesius class VIII SMP Negeri 1 Kediri academic year 2018/2019.
\end{abstract}

Keywords: cooperative learning type (STAD) and (NHT); learning achievement

\begin{abstract}
Abstrak
Penelitian ini bertujuan untuk mengetahui apakah ada perbedaan prestasi belajar matematika antara kelas yang diajar dengan model pembelajaran kooperatif tipe Student Team Achievement Division (STAD) dan kelas yang diajar dengan model pembelajaran kooperatif tipe Numbered Head Together (NHT) pada materi sistim koordinat kartesius kelas VIII SMP Negeri 1 Kediri tahun pelajaran 2018/2019. Tekhnik pengumpulan data dalam penelitian ini adalah tekhnik tes dengan instrumen berupa tes prestasi belajar, lembar observasi keterlaksanaan pembelajaran dan rencana pelaksanaan pembelajaran. Tekhnik analisis data menggunakan statistik deskriptif. Uji hipotesis kemampuan akhir siswa (posstest) dengan uji-t dua pihak pada taraf signifikansi $5 \%$ menghasilkan thitung $\leq t_{\text {tabel }}$ yaitu $0,020 \leq 2.030$ yang berarti bahwa tidak ada perbedaan prestasi belajar matematika antara kelas yang diajar dengan model pembelajaran kooperatif tipe Student Team Achievement Division (STAD) dan kelas yang diajar dengan model pembelajaran kooperatif tipe Numbered Head Together (NHT) pada materi sistim koordinat kartesius kelas VIII SMP Negeri 1 Kediri tahun pelajaran 2018/2019.
\end{abstract}

Kata Kunci: pembelajaran kooperatif tipe STAD dan NHT; prestasi belajar

\section{PENDAHULUAN}

Prestasi siswa dalam pembelajaran matematika di Indonesia masih tergolong rendah. Hal ini didukung oleh beberapa data hasil studi internasional yang menunjukkan bahwa prestasi matematika siswa Indonesia berada di peringkat bawah. Data 
Programme for International Student Assesment (PISA) untuk bidang matematika pada tahun 2015 menunjukkan bahwa rata-rata nilai matematika di Indonesia adalah 386 (peringkat 69 dari 76 negara). Nilai ini jauh di bawah Negara-negara Asia Tenggara lainnya seperti Vietnam menduduki peringkat ke-12 dari 76 negara (Kemendikbud, 2016).

Fakta yang terjadi di SMP Negeri 1 Kediri juga menunjukkan rendahnya prestasi belajar matematika siswa. Hal ini terlihat dari rata-rata nilai hasil belajar peserta didik pada materi sistim koordinat kartesius tahun pelajaran 2017/2018 yang tercantum pada tabel 1 . berikut ini.

Tabel 1. Rata-Rata Nilai Hasil Belajar Peserta Didik Pada Materi Sistem Koordinat Kartesius Tahun Pelajaran 2017/2018

\begin{tabular}{cccc}
\hline No & Kelas & Banyak Siswa & Rata-Rata \\
\hline 1 & VIII-A & 36 & 52 \\
\hline 2 & VIII-B & 35 & 48 \\
\hline 3 & VIII-C & 24 & 53 \\
\hline 4 & VIII-D & 26 & 31 \\
\hline 5 & VIII-E & 25 & 31 \\
\hline \multicolumn{2}{l}{ Sumber: } & Data Nilai Guru Matematika SMPN 1 Kediri
\end{tabular}

Informasi yang didapatkan dari guru mata pelajaran matematika kelas VIII adalah nilai rata-rata ulangan harian peserta didik kelas VIII diambil dari nilai pengetahuan semester ganjil untuk tahun pelajaran 2017/2018 masih dibawah kriteria ketuntasan Minimum (KKM) dimana nilai KKM untuk mata pelajaran matematika yang digunakan di SMPN 1 Kediri adalah 71.

Kemudian Berdasarkan hasil observasi dan wawancara yang kedua kalinya dengan guru bidang studi pendidikan matematika didapat bahwa pembelajaran yang berpusat pada guru (teacher centered) dimana guru dijadikan satu-satunya sumber pembelajaran oleh peserta didik. Sehingga, pesera didik tidak dapat menyampaikan ide-idenya dalam diskusi kelompok sebagai dampak dari teacher centered tersebut. Selain itu, peserta didik yang memiliki kemampuan akademik rendah masih kesulitan untuk menyerap pelajaran yang disampaikan oleh guru dibandingkan dengan siswa yang berkemampuan akademik tinggi. Hal ini mengakibatkan kurangnya penguasaan pada materi sistim koordinat kartesius oleh peserta didik. Peserta didik hanya mendengarkan materi pelajaran dari guru dan siswa tidak dapat menyampaikan ideide yang di miliki.

Kemudian saat diskusi kelompok berlangsung, belum terciptanya interaksi belajar yang baik dalam diskusi kelompok. Sehingga hanya sebagian peserta didik dalam anggota kelompok yang berdiskusi dan yang lainnya berfokus pada kegiatan lainnya. Peserta didik juga masih merasa kesulitan untuk menguasai dan memahami materi yang 
diajarkan oleh guru. Hal ini mengakibatkan rendahnya prestasi belajar pada siswa kelas VIII SMP Negeri 1 Kediri.

Hal ini melatarbelakangi hadirnya beberapa model pembelajaran yang inovatif untuk membantu peserta didik memahami materi yang akan disampaikan oleh guru. Suatu pembelajaran akan lebih berarti apabila siswa bereksperimen sendiri daripada mendengarkan ceramah guru. Khusunya pada pembelajaran matematika, hendaknya guru menggunakan model pembelajaran dimana peserta didik berpartisipasi aktif dalam diskusi guna untuk memahami dan mengerti apa yang disampaikan oleh guru sehingga peserta didik sendiri bisa merasakan ilmu yang diberikan. Salah satu model pembelajaran yang dimaksud adalah model pembelajaran kooperatif. Menurut Isjoni (2010), dalam pembelajaran kooperatif, siswa terlibat dalam diskusi, bekerja sama antara satu dengan yang lainnya dan mendengarkan pendapat siswa yang lain bahkan menyampaikan atau mempersentasikan hasil dari kerja kelompok.

Ada beberapa tipe model pembelajaran kooperatif antara lain yaitu model pembelajaran kooperatif tipe Student Team Achievement Division (STAD) dan model pembelajaran kooperatif tipe Numbered Head Together (NHT). Model pembelajaran kooperatif tipe Student Team Achievement Division merupakan model pembelajaran kooperatif yang menekankan adanya aktivitas dan interaksi diantara siswa untuk saling membantu dalam menguasai materi pelajaran guna mencapai prestasi yang maksimal (Isjoni, 2012). Ada beberapa Langkah pada Model Pembelajaran kooperatif tipe Student Team Achievement Division (STAD) (Suprijono, 2009) yaitu: 1. Membentuk Kelompok yang anggotanya 4 orang secara heterogen (campuran menurut prestasi, jenis kelamin, suku dan lain-lain),2. Guru menyajikan pelajaran 3. Guru memberi tugas kepada kelompok untuk dikerjakan oleh anggota-anggota kelompok. Anggotanya yang sudah mengerti dapat menjelaskan pada anggota lainnya sampai semua anggota dalam kelompok itu mengerti, 4. Guru memberi kuis/pertanyaan kepada seluruh siswa. Pada saat menjawab kuis tidak boleh saling membantu ,5. Memberi evaluasi dan 6. Kesimpulan. Selain tipe Student Team Achiievement Division (STAD), tipe pembelajaran kooperatif lainnya adalah Numbered Head Together (NHT). Menurut Hamdayama (2015), pembelajaran kooperatif tipe Numbered Head Together (NHT) merupakan salah satu tipe pembelajaran kooperatif yang menekankan pada struktur khusus yang dirancang untuk mempengaruhi pola interaksi siswa dan memiliki tujuan untuk meningkatkan penguasaan akademik. Tipe ini dikembangkan oleh Ibrahim (dalam Hamdayana, 2015) dengan melibatkan para siswa dalam menelaah bahan yang tercakup dalam suatu pelajaran dan mengecek pemahaman mereka terhadap isi pelajaran tersebut.

Berdasarkan uraian di atas, maka penelitian dengan judul Studi Perbandingan model pembelajaran kooperatif tipe Student Team Achievement Division (STAD) dengan kooperatif tipe Numbered Head Together (NHT) pada materi sistim koordinat kartesius kelas VIII SMP Negeri 1 Kediri Tahun Pelajaran 2018/2019 perlu untuk dilakukan. 


\section{METODE PENELITIAN}

Penelitian ini tegolong penelitian eksperimen semu (Quasi Eksperimental Design). Populasi dalam penelitian ini adalah seluruh siswa kelas VIII-A sampai dengan kelas VIII-E dengan jumlah 146 peserta didik. Sampling dilakukan dengan menggunakan teknik purposive sample dimana sampel tidak dipilh secara acak (random) sehingga diperoleh kelas VIII-D sebagai kelas eksperimen 1 dan kelas VIII-E sebagai kelas eksperimen 2. Kedua kelompok tersebut diberikan posttest. Pada kelas eksperimen 1 diberikan perlakuan berupa penerapan model pembelajaran kooperatif tipe Student Team Achievement Division (STAD), sedangkan pada kelas eksperimen 2 diberikan perlakuan berupa penerapan model pembelajaran kooperatif tipe Numbered Head Together (NHT).

Teknik pengumpulan data menggunakan teknik tes untuk memperoleh data prestasi belajar matematika siswa materi sistim koordinat kartesius. Instrumen yang digunakan berupa tes prestasi belajar, lembar observasi dan Rencana Pelaksanaan Pembelajaran (RPP), dan RPP yang digunakan sebagai acuan bagi guru untuk melaksanakan kegiatan belajar mengajar (kegiatan pembelajaran) agar lebih terarah dan berjalan secara efektif dan efisien.

Uji instrumen dalam penelitian ini digunakan untuk menguji kelayakan instrumen dalam mengukur prestasi belajar matematika siswa. Uji instrumen dilakukan dengan menggunakan:

\subsection{Uji Validitas}

Validitas adalah suatu ukuran yang menunjukan tingkat-tingkat kevalidan atau kesasihan suatu instrument. Suatu instrument yang valid atau sahih memiliki validitas tinggi. Sebaliknya, instrument yang kurang valid berarti memiliki validitas rendah (Arikunto, 2010).

\subsection{Uji Normalitas}

Uji normalitas data dilakukan untuk data tes akhir. Pengujian ditunjukkan untuk mengetahui apakah data tes akhir berdistribusi normal atau tidak. Menurut Riduwan (2013), uji normalitas data dapat dilakukan dengan berbagai cara, yaitu dengan uji chi kuadrat.

\subsection{Uji Hipotesis (uji-t)}

Untuk mengetahui apakah ada perbedaan prestasi belajar matematika antara kelas yang diajar dengan model pembelajaran kooperatif tipe Student Team Achievement Division (STAD) dan kelas yang diajar dengan model pembelajaran kooperatif tipe Numbered Head Together (NHT) pada siswa kelas VIII SMP Negeri 1 Kediri tahun pelajaran 2018/2019, maka data tes akhir diolah dengan menggunakan uji-t dua pihak. Uji hipotesis yang akan digunakan adalah uji-t dua pihak pada taraf signifikansi $5 \%$. 
Pengujian hipotesis menggunakan rumus t-tes, dengan pedoman penggunaan sebagai berikut:

Bila $n_{1} \neq n_{2}$, varian normal, dapat digunakan rumus t-test dengan pooled varian. Dengan derajat kebebasan $(\mathrm{db})=n_{1}+n_{2}-2$.

$$
t=\frac{\bar{X}_{1-\bar{X}_{2}}}{\sqrt{\frac{\left(n_{1}-1\right) s_{1}^{2}+\left(n_{2}-1\right) s_{2}^{2}}{n_{1}+n_{2}-2}\left(\frac{1}{n_{1}}+\frac{1}{n_{2}}\right)}}
$$

(Sugiyono, 2014)

Keterangan:

$\mathrm{t}=$ Nilai $\mathrm{t}$ hitung

$\bar{X}_{1}=$ Nilai rata-rata kelas ekperimen 1

$\bar{X}_{2}=$ Nilai-rata-rata kelas ekperimen 2

$s_{1}{ }^{2}=$ Varians kelas ekperimen 1

$s_{2}{ }^{2}=$ Varians kelas ekperimen 2

$n_{1}=$ Jumlah sampel kelas ekperimen 1

$n_{2}=$ jumlah sampel kelas ekperimen 2

Nilai $t$ yang diperoleh disebut $t_{\text {hitung }}$ kemudian dibandingkan dengan nilai $t_{\text {tabel }}$ pada taraf signifikansi $5 \%$ dengan ketentuan sebagai berikut:

1. Jika $t_{\text {hitung }}>t_{\text {tabel, }}$, maka Ho ditolak dan Ha diterima

2. Jika $t_{\text {hitung }} \leq t_{\text {tabel, }}$ maka Ho diterima dan Ha ditolak

Nilai $t_{\text {tabel }}$ dihitung menggunakan rumus interpolasi karena nilai $\mathrm{db}$ pembilang tidak dapat langsung ditemukan pada tabel. Adapun rumus interpolasi yang digunakan sebagai berikut:

$C=C_{o}+\frac{C_{1}-C_{o}}{B_{1}-B_{o}}\left(B-B_{o}\right)$

(Riduwan, 2014)

Keterangan:

$B \quad=$ Nilai db yang dicari

$B_{0} \quad=$ Nilai db pada awal nilai yang sudah ada

$B_{1}=$ Nilai db pada akhir nilai yang sudah ada

$C=$ Nilai $t_{\text {tabel }}$ yang dicari

$C_{o}=$ Nilai $t_{\text {tabel }}$ pada awal niali yang sudah ada

$C_{1}=$ Nilai nilai $t_{\text {tabel }}$ pada akhir yang sudah ada

Setelah diperoleh harga $t_{\text {hitung, }}$ kemudian dibandingkan dengan harga $t_{\text {tabel }}$ dengan $\mathrm{db}=n_{1}+n_{2}-2$ dan taraf kepercayaan 95\% (taraf signifikansi $5 \%$ ). Dengan kriteria pengujiannya: apabila $t_{\text {hitung }}>t_{\text {tabel }}$ maka koefisiensi korelasi tersebut signifikan. Hipotesis statistik yang akan diuji adalah sebagai berikut: 
$\mathrm{Ha}=$ Ada perbedaan prestasi belajar matematika antara kelas yang diajar dengan model pembelajaran kooperatif tipe Student Team Achievement Division (STAD) dan kelas yang diajar dengan model pembelajaran kooperatif tipe Numbered Head Together (NHT) pada materi sistim koordinat kartesius kelas VIII SMP Negeri 1 Kediri Tahun Pelajaran 2018/2019.

Ho = Tidak ada perbedaan prestasi belajar matematika antara kelas yang diajar dengan model pembelajaran kooperatif tipe Student Team Achievement Division (STAD) dan kelas yang diajar dengan model pembelajaran kooperatif tipe Numbered Head Together (NHT) pada materi sistim koordinat kartesius kelas VIII SMP Negeri 1 Kediri tahun ajaran 2018/2019.

\section{HASIL DAN PEMBAHASAN}

Hasil dan diskusi berisi temuan dan diskusi penelitian ilmiah. Tuliskan temuantemuan ilmiah yang diperoleh dari hasil penelitian yang telah dilakukan tetapi harus didukung oleh data yang memadai. Temuan ilmiah yang dimaksud di sini bukanlah hasil dari data penelitian yang diperoleh. Temuan ilmiah harus dijelaskan secara ilmiah termasuk: Temuan ilmiah apa yang diperoleh? Mengapa itu terjadi? Mengapa variabel tren seperti itu? Semua pertanyaan ini harus dijelaskan secara ilmiah, tidak hanya deskriptif jika perlu didukung oleh fenomena dasar ilmiah yang memadai. Selain itu, itu juga harus dijelaskan dibandingkan dengan hasil peneliti lain yang hampir topik yang sama. Hasil penelitian dan temuan harus dapat mengakomodasi tujuan penelitian dalam pendahuluan.dilakukan.

\subsection{Normalitas Data}

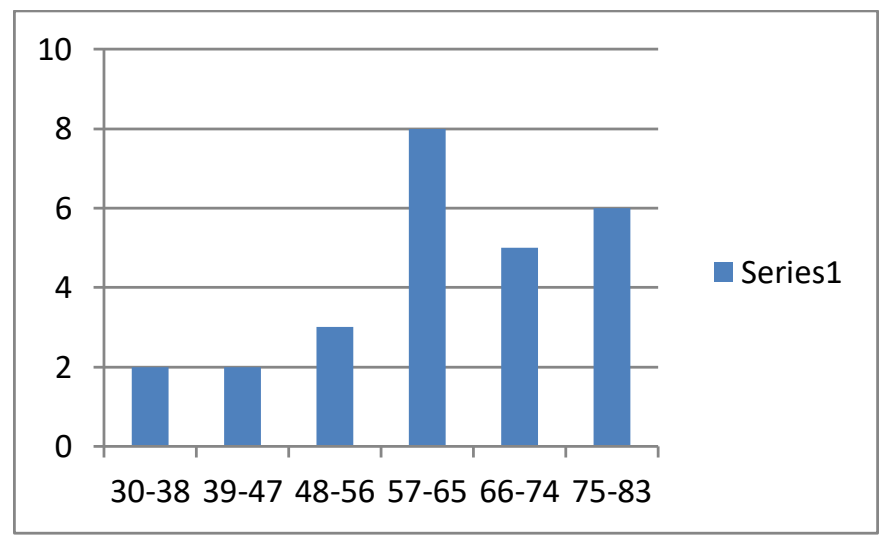

Gambar 1. Diagram Batang Data Postest Kelas Eksperimen 1

Grafik diatas menunjukan bahwa terdapat 6 interval kelas berdasarkan prestasi belajar (posstest) siswa pada kelas eksperimen 1, yaitu dengan rentang nilai 30-38, 3947, 48-56, 57-65, 66-74 dan 75-83. Terdapat 2 peserta didik yang mendapat nilai pada interval 30-38, 2 peserta didik yang mendapat nilai pada interval 39-47, 3 peserta didik yang mendapat nilai pada interval $48-56,8$ peserta didik yang mendapat nilai pada 
interval 57-65, dan 5 peserta didik yang mendapat nilai pada interval 66-74 dan 6 peserta didik yang mendapat nilai pada interval 75-83.

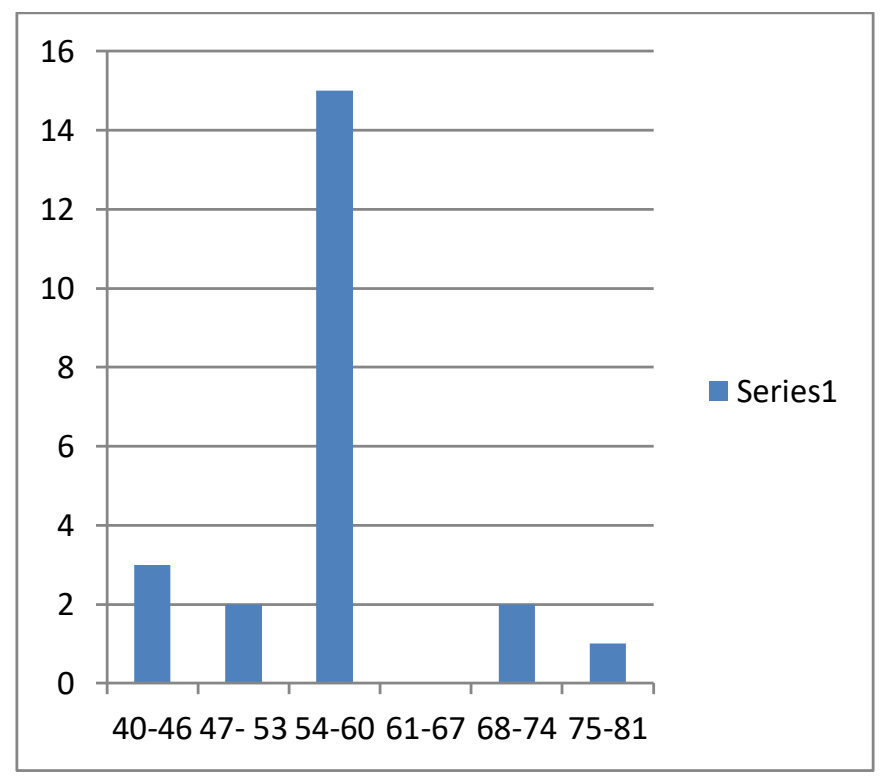

Gambar 2. Diagram Batang Data Posttest Kelas Eksperimen 2

Grafik diatas menunjukan bahwa terdapat 6 interval kelas berdasarkan prestasi belajar (posttest) siswa pada kelas eksperimen 2, yaitu dengan rentang nilai 40-46, 47$53,54-60,61-67,68-74$ dan 75-81. Terdapat 3 peserta didik yang mendapat nilai pada interval 40-46, 2 peserta didik yang mendapat nilai pada interval 47-53, 15 peserta didik yang mendapat nilai pada interval 54-60, tidak ada peserta didik yang mendapat nilai pada interval 61-67, 2 peserta didik yang ada pada interval 68-74, dan 1 peserta didik yang mendapat nilai pada interval 75-81.

\subsection{Uji Hipotesis}

Setelah kedua persyaratan terpenuhi yaitu kedua kelas tersebut berdistribusi normal dan homogeny, maka uji hipotesis dapat dilakukan dengan menggunakan uji-t yang bertujuan untuk mengetahui apakah ada perbedaan prestasi belajar matematika antara kelas yang diajar dengan model pembelajaran kooperatif tipe Student Team Achievement Division (STAD) dan kelas yang diajar dengan model pembelajaran kooperatif tipe Numbered Head Together (NHT) pada siswa kelas VIII SMP Negeri 1 Kediri Tahun Pelajaran 2018/2019. Uji Hipotesis dalam penelitian ini meggunakan uji-t dua pihak mengunakan rumus t-test dengan polled variandengan kriteria pengujan yaitu jika thitung $\leq t_{\text {tabel }}$, maka Ho diterima dan Ha ditolak pada taraf signifikansi $5 \%$ Hasil uji-t dari post-test prestasi belajar matematika dapat dilihat pada lampiran.

Berdasarkan tabel tersebut, dapat dilihat $t_{\text {hitung }} \leq t_{\text {tabel }}$ yaitu $0,020 \leqq 2,030$ pada taraf signifikan $5 \%$ dengan derajat kebebasan $(\mathrm{dk})=\mathrm{n}_{1}+\mathrm{n}_{2}-2=26+25-2=49$. sesuai dengan kriteria pengujian hipotesis yaitu $t_{\text {hitung }} \leq \mathrm{t}$ tabel, maka Ho diterima dan Ha ditolak. Hal ini menunjukan bahwa tidak ada perbedaan prestasi belajar matematika antara kelas 
yang diajar dengan model pembelajaran tipe Student Team Achievement Division (STAD) dam kelas yang diajar dengan model Numbered Head Together (NHT).

Berdasarkan pemaparan sebelumnya menunjukkan bahwa kedua kelas sama-sama belum pernah diberikan perlakuan dengan model pembelajaran kooperatif, yang artinya kedua kelas tersebut yaitu kelas VIII-D dan kelas VIII-E tidak memiliki perbedaan pada kemampuan awal, sehingga dapat disimpulkan bahwa kemampuan awal kelas VIII-D dan kelas VIII-E masih dalam kondisi yang sama, jadi kelas tersebut dapat digunakan sebagai kelas eksperimen 1 dan kelas eksperimen 2 .

Selanjutnya, peneliti memberikan perlakuan berupa penerapan model pembelajaran kooperatif tipe Student Team Achievement Division (STAD) dan model pembelajaran kooperatif tipe Numbered Head Together (NHT). Setelah memberikan perlakuan, peneliti melanjutkan ke tahap posttest yang bertujuan untuk melihat perbedaan prestasi belajar antara kelas yang di ajar dengan model pembelajaran kooperatif tipe Student Teams Achievement Divisions (STAD) dan siswa yang diajar dengan model pembelajaran kooperatif tipe Numbered Head Together (NHT). Pada tahap posttest, peneliti memberikan soal sebanyak 3 butir kepada kedua kelas dengan materi yang sama materi yang dimaksud yaitu sistim koordinat kartesius.

Kelas eksperimen 1 memperoleh rata-rata nilai lebih tinggi dibandingkan dengan kelas eksperimen 2 dikarenakan kelaas eksperimen 1 lebih antusias dalam menerima pembelajaran, kelas eksperimen 1 mendapat rata-rata nilai 62,38 lebih tinggi dari kelas eksperimen 2 yaitu 52,16 dan selisih antara rata-rata nilai kelas eksperimen 1 dan kelas eksperimen 2 yaitu 10,22.

Selanjutnya, hasil tes akhir (posttest) digunakan untuk perhitungan uji normalitas. Uji normalitas digunakan untuk mengolah data tes akhir (posttest) yang bertujuan untuk menentukan tindak lanjut uji beda (uji-t) yang akan digunakan. Berdasarkan hasil uji normalitas tes akhir (posttest) kelas eksperimen 1 dan kelas eksperimen 2,diperoleh

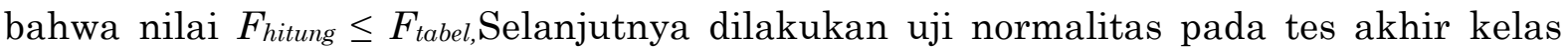
eksperimen 1 dan kelas eksperimen 2, diperoleh bahwa $\chi^{2}{ }_{\text {hitung }} \leq \chi^{2}$ tabelmaka berdasarkan kriteria penentuan Sugiyono (2014) data tes akhir tersebut berdistribusi normal. Sehingga, diperoleh bahwa kedua kelas setelah diberi perlakuan memiliki data yang berdistribusi normal.

Setelah mengetahui normalitas kedua kelas, selanjutnya peneliti menganalisa hipotesis yang telah di paparkan pada bab sebelumnya, yaitu dengan menggunakan rumus $t$-test polled varians. Ternyata setelah dilakukan uji hipotesis dengan menggunakan uji-t dengan taraf signifikasi 5\% pada tingkat kepercayaan 95\% peneliti memperoleh hasil

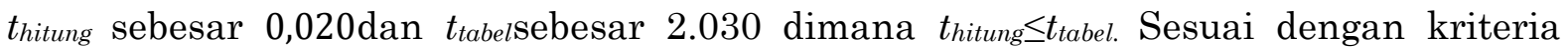
pengujian hipotesis menurut (Sugiyono, 2014), jika $t_{\text {hitung }} \leq t_{\text {tabel }}$ maka hipotesis alternative (Ha) dinyatakan ditolak dan hipotesis (Ho) dinyatakan diterima. Sehingga dapat dinyataka bahwa, tidak ada perbedaan prestasi belajar matematika antara kelas yang diajar dengan model pembelajaran kooperatif tipe Student Team Achievement 
Division (STAD) dan kelas yang diajar dengan model pembelajaran kooperatif Numbered Head Together (NHT) pada siswa kelas VIII SMP Negeri 1 Kediri tahun pelajaran 2018/2019.

Berdasarkan hasil observasi kegiatan guru dan siswa yang dilakukan selama penelitian, terlihat bahwa aktivitas guru dan siswa pada kedua kelas tersebut sudah baik. Guru melaksanakan kegiatan pembelajaran sesuai dengan skenario yang telah disusun dalam rencana pelaksanaan pembelajaran (RPP). Guru aktif dalam mendampingi dan membimbing siswa selama pembelajaran berlangsung. Begitupun dengan siswa, terjadi peningkatan keaktifan siswa selama proses pembelajaran berlangsung dari tiap pertemuan. Hal tersebut terlihat dari persiapan dan antusiasme siswa dalam mengikuti kegiatan pembelajaran, siswa sudah berani mengajukan pertanyaan dan menyampaikan pendapat pada saat diskusi berlangsung. Akan tetapi, beberapa kelompok di kelas eksperimen 2 yang menggunakan model pembelajaran kooperatif tipe Numbered Head Together (NHT), pada kelas tersebut terdapat beberapa kelompok yang tidak dapat memecahkan soal yang diberikan oleh guru. Hal ini dikarenakan peserta didik masih main-main dalam mengerjakan soal yang diberikan guru.

Meskipun di kelas tersebut juga berkelompok, tetapi anggota kelompoknya hanya terdiri dari dua orang atau berpasangan. Oleh karena itu, dengan minimnya anggota kelompok, maka tidak banyak ide yang muncul. Ketika kedua siswa tersebut tidak dapat memecahkan persoalan yang sedang mereka hadapi, maka tidak ada siswa lain lagi yang dapat memberikan solusi, akibatnya keduanya mengalami kebingungan sehingga materi tidak dapat dengan baik. Hal ini sesuai dengan pendapat yang di kemukakan oleh (Asma, 2006) yang menyatakan bahwa masing-masing kelompok hanya terdiri dari dua siswa sehingga seringkali menggantungkan pada pasangan dan lebih sedikit ide yang masuk. Berdasarkan pernyataan tersebut, dengan sedikitnya ide yang masuk dan kurangnya komunikasi yang baik antar siswa dalam pasangan maka tingkat pemahaman terhadap materi pembelajaran menjadi kurang sehingga dapat berpengaruh pada prestasi belajar yang kurang maksimal.

Berbeda dengan kelas eksperimen 1 yang menggunakan model pembelajaran kooperatif tipe Student Teams Achievement Divisions (STAD), yaitu pada model tersebut pembagian kelompoknya terdiri dari 4-5 siswa sehingga lebih banyak ide yang muncul. Ketika salah satu siswa mengalami kesulitan, maka masih ada siswa lainnya yang dapat memberikan solusi untuk mengatasi kesulitan tersebut. Dengan demikian, materi sesulit apapun dapat dipahami oleh siswa. Hal ini sesuai dengan pendapat (Rusman, 2011) yang menyatakan bahwa model tersebut dapat mengurangi sifat individualistis siswa, seperti sikap tertutup terhadap teman, kurang memberi perhatian kepada teman sekelas, dan bergaul hanya dengan orang tertentu. 
Selain itu, berdasarkan hasil posttest dan pengamatan dengan menggunakan lembar observasi selama proses pembelajaran berlangsung, dapat diketahui bahwan kelas eksperimen 1 yang menggunakan model pembelajaran kooperatif tipe Student Teams Achievement Divisions (STAD) terlihat bahwa siswa saling membantu dalam menyelesaikan latihan kelompok. Dengan keberagaman kemampuan siswa dalam kelompok, siswa yang kemampuan matematikanya kurang bisa mendapat bantuan penjelasan dari anggota kelompok lain yang mempunyai kemampuan yang lebih tinggi.

Hal itu sesuai dengan pendapat (Rusman, 2011) yang menyatakan bahwa siswa tidak hanya bekerja secara individu tetapi juga dapat bekerja secara kelompok, serta memberikan kesempatan kepada semua siswa untuk terlibat aktif dalam kegiatan pembelajaran. Siswa yang berkemammpuan tinggi dapat mengajari teman kelompoknya dengan system tutor sebaya agar dapat berhasil menyelesaikan tugas yang diberikan guru. Pernyataan tersebut menunjukkan bahwa siswa akan berusaha keras melalui kerja tim untuk menjadi yang lebih baik dalam hal memahami materi pembelajaran sehingga dapat memperoleh prestasi belajar yang tinggi. Slavin (2005) juga menyatakan bahwa pada kegiatan kerja tim, para siswa bertanggung jawab untuk memastikan satu tim mereka telah mempelajari materinya dan tidak ada yang boleh berhenti belajar sampai semua teman satu tim menguasai pelajaran tersebut. Selain itu, siswa yang berkemampuan tinggi dapat membantu temannya untuk menguasai materi sebelum siswa tersebut bertanya kepada guru jika siswa yang berkemampuan tinggi dalam kelompok tidak mengetahuinya. Dalam prakteknya, guru meminta seorang siswa yang berkemampuan paling tinggi untuk bertanggung jawab mengajari siswa yang belum bisa dan semua siswa dalam tim yang paham boleh membantu siswa lainnya dalam satu tim yang belum paham.

Sedangkan untuk kelas eksperimen 2 yang menggunakan model pembelajaran kooperatif tipe Numbered Head Together (NHT), beberapa kelompok terlihat kebingungan karena siswa yang kebingungan tidak bisa bertanya kepada teman sebangkunya atau pasangannya. Hal itu karena teman sebangkunya juga mengalami kebingungan dalam memahami materi yang sedang dipelajari. Oleh karena itu, kondisi tersebut berpengaruh pada prestasi belajar matematika siswa seperti yang telah dijelaskan di atas bahwa prestasi belajar matematika siswa yang diajar dengan model pembelajaran kooperatif tipe Student Teams Achievement Divisions (STAD) lebih tinggi dibandingkan dengan siswa yang diajar dengan model pembelajaran kooperatif tipe Numbered Head Together (NHT).

Berdasarkan pada uraian hasil penelitian yang telah di jelaskan di atas, menunjukkan bahwa tidak ada perbedaan prestasi belajar matematika antara kelas yang diajar dengan model pembelajaran kooperatif tipe Student Team Achievement Division (STAD) dan kelas yang diajar dengan model pembelajaran kooperatif tipe Numbered Head Together (NHT) pada materi sistim koordinat kartesius kelas VIII SMP Negeri 1 Kediri tahun pelajaran 2018/2019. Selain itu, pembelajaran yang menggunakan model pembelajaran kooperatif tipe Student Teams Achievement Divisions (STAD) lebih baik 
digunakan dalam meningkatkan prestasi belajar matematika siswa dibandingkan dengan pembelajaran yang menggunakan model pembelajaran kooperatif tipe Numbered Head Together (NHT).

\section{SIMPULAN}

Berdasarkan hasil penelitian dan pembahasan pada BAB IV dan BAB V, maka dapat disimpulkan bahwa: nilai thitung $\leq t_{\text {tabel }}$ ini menunjukan bahwa tidak terdapat perbedaan prestasi belajar matematika antara kelas yang diajar dengan model pembelajaran kooperatif tipe Student Team Achievement Division (STAD) dan kelas yang diajar dengan model pembelajaran Numbered Head Together (NHT) pada materi sistim koordinat kartesius kelas VIII SMP Negeri 1 Kediri Tahun Pelajaran 2018/2019.

\section{REKOMENDASI}

1. Bagi Guru

Dengan menerapkan model pembelajaran kooperatif tipe Student Team Achievement Division (STAD) dan Numbered Head Together (NHT) diharapkan dapat memperoleh wawasan tentang model pembelajaran aktif dan memberi pengalaman baru kepada guru dalam mengembangkan kreativitasnya terhadap pembelajaran sehingga dapat meningktakan prestasi belajar siswa khususnya pada mata pelajaran matematika.

2. Bagi Sekolah

Sekolah hendaknya mendukung dan mendorong guru untuk menerapkan model pembelajaran yang dapat meningkatkan partisipasi siswa dalam pembelajaran, menyediakan fasilitas yang memadai untuk mempermudah guru dalam menerapkan model pembelajaran yang bervariasi, salah duanya model pembelajaran kooperatif tipe Numbered Head Together (NHT) dan Student Team Achievement Division (STAD).

3. Bagi Peserta Didik

Peserta didik sebaiknya lebih aktif ketika proses pembelajaran berlangsung, bertanya kepada guru apabila ada yang masih belum dipahami, aktif dalam diskusi kelompok sehingga meningkatkan prestasi belajarnya.

4. Bagi Peneliti atau Mahasiswa

Peneliti atau mahasiswa lain yang akan melakukan penelitian agar dapat memperbaiki kekurangan yang terjadi dalam penelitian ini sehingga hasil peneliti selanjutnya menjadi lebih baik terutama dalam penerapan model pembelajaran kooperatif tipe Numbered Head Together (NHT) dan Student Team Achievement Division (STAD).

\section{REFERENSI}

Asma, N. (2006). Model pembelajaran kooperatif. Jakarta: Direktorat Jendral Pendidikan Tinggi. Arikunto, S. (2014). Prosedur penelitian suatu pendekatan praktik. Jakarta: Rineka Cipta.

Hamdani. (2010). Strategi belajar mengajar. Bandung: Pustaka Setia.

Hamalik, O. (2009). Kurikulum dan pembelajaran. Jakarta: Bumi Aksara. 
Mulyasa, E. (2006). Kurikulum berbasis kompetensi. Remaja Rosdakarya

Hamdayana, J. (2015). Model dan metode pembelajaran kreatif dan berkarakter. Bogor: Ghalia Indonesia.

Kurniasih, I. \& Sani, B. (2015). Ragam pembelajaran dan model pembelajaran. Jakarta: Kata Pena.

Isjoni. (2012). Cooperative learning. Bandung: Alfabet.

Jihad, A. (2009). Evaluasi pembelajaran. Yogyakarta: Multi Presindo.

Kemendikbud. (2016). PISA 2016. Diakses pada tanggal 25 April 2018 dari (http://www.kemendikbud.go.id/main/blog/2018/4/peringkat-dan-capaian-pisa-indonesiamengalami-peningkatan.html? $\mathrm{m}=1$ )

Riduwan. (2013). Dasar-dasar statistika. Bandung: Alfabeta.

Rusman. (2011). Model-model pembelajaran (mengembangkan profesionalisme guru). Jakarta: Rajawali Press.

Slavin, R. E. (2005). Cooperative learning teori, risert, dan praktik. (Alih bahasa: Narilita Yusron). Bandung: Nusa Media.

Sugiyono. (2014). Metode penelitian kuantitatif, kualitatif, dan $r \& d$. Bandung: Alfabeta.

Suprijono, A. (2012). Cooperative learning teori dan aplikasi palkem. Yogyakarta: Pustaka Pelajar. 